Florida A\&M University College of Law

Scholarly Commons @ FAMU Law

Fall 2018

Advising 2.0: Helping Students Achieve Academic Success

Through Meaningful Academic Advising

Alicia Jackson

Follow this and additional works at: https://commons.law.famu.edu/faculty-research

Part of the Legal Education Commons 


\section{Advising 2.0: Helping Students Achieve Academic Success through Meaningful Academic Advising}

\author{
"To aid our \\ students \\ in achiev- \\ ing aca- \\ demic suc- \\ cess, it is \\ essential \\ that we \\ under- \\ stand the \\ complex \\ needs of \\ our stu- \\ dents by \\ first exam- \\ ining their \\ previous \\ education- \\ al experi- \\ ences."
}

\author{
Alicia Jackson \\ Associate Dean for Student \\ Learning and Assessment \\ Florida AEM University, \\ College of Law
}

It is becoming increasingly clear that current law students are seeking more wraparound support than previously provided by legal education, which begs the question, why? The answer is simple modern law students are different and come to law school with very different expectations and experiences than students from previous years. To aid our students in achieving academic success, it is essential that we understand the complex needs of our students by first examining their previous educational experiences.

Academic advising is commonplace at institutions that serve undergraduate students. In fact, some would argue that academic advising is the cornerstone of student suc-

cess. Advising at the undergraduate level is viewed as a collaborative relationship between student and advisor that is designed to provide the meaningful support students need to achieve their academic goals throughout matriculation. Professional academic advisors, academic support and academic resource centers are as common to undergraduate students as hornbooks and supplements (or Westlaw and Lexis) are to law students.

Millennials make up the largest population of students currently in law school. Millennials often come to law school with the expectation they will receive academic advising and support similar to their undergraduate academic experience. However, to students' surprise, law school generally does not provide the level of advising that Millennials are used to receiving. This often leaves law students feeling as though they are lost in the process of academic planning, and far too often results in students relying on their classmates for academic planning advice. In fact, more law students are noting the lack of academic advising and basic course planning assistance in their graduation exit surveys.

American Bar Association (ABA) Standard 309 provides, "(a) A law school shall provide academic advising for students that communicates effectively the school's academic standards and graduation requirements, and that provides guidance on course selection." While most law schools don't have a designated "academic advisor" per se, all law schools provide a form of academic advising. The most widely used method is the faculty advising system. While faculty advising is beneficial, some would argue it is not the best method for providing specific and targeted academic advising. The traditional faculty academic advising system often lacks depth and understanding of the particular needs of this generation, thus failing to provide the level of support needed by this new generation of learners. To that end, the level of specificity and support intended by ABA Standard 309 can often be missed in the traditional law school faculty advising system.

While I am strongly advocating for the need for more formalized "academic advising" to meet the needs of today's law students and the intended goals of ABA Standard 309, in no way am I suggesting that having a professional academic advisor replaces the need for, and purpose of, 
faculty advisors. The role of faculty advisors is an extremely important component of the law school experience. Faculty advisors help students in many ways, including serving as support for students adjusting to the rigors of law school, providing invaluable career planning guidance, and serving as a mentor to provide meaningful information and advice about law school in general. In addition to their role advising students, faculty members have numerous other responsibilities, including teaching, scholarship, and internal and external service. To the contrary, the only major responsibility of professional academic advisors is student advising, which often results in academic advisors being more readily available to assist students. While having a professional academic advisor does not replace the need for a faculty advisor, having a dedicated academic advisor can serve to readily meet the course planning needs of students.

Professional academic advisors are focused primarily on "planning", and ideally can help students "plan for success" early in their law school experience. Academic advisors can assist students in developing a formal plan for ensuring they are not only aware of academic policies, but are able to customize a plan that is right for them. Through the planning process students are encouraged to make decisions that support their goals, abilities and aspirations. The academic planning process can also lead to greater student accountability and student buy-in to the law school planning process. This process is further strengthened when there is collaboration between faculty advisors and professional academic advisors. In fact, faculty advisors play a key role in the process by strongly encouraging their advisees to seek out an academic advisor for course planning assistance.

Another major benefit of having a law school professional academic advisor is strategic and targeted advising. Having a dedicated academic advisor provides an additional resource and support mechanism for students that are experiencing academic difficulty. An unintended result of the voluntary faculty advising system is that the students who need the most guidance are often the last to seek it. In addition, some law students do not feel comfortable expressing academic concerns to a "professor" for fear of being labeled or judged by the people they hold in such high regard. This often results in a law school's most vulnerable students falling through the cracks. The nonfaculty academic advisor has the ability to create a judgement free zone where students feel welcome and free to express concerns and engage openly in the planning process, without thinking twice about being judged. An example of targeted advising and support would be the law school requiring students on academic probation or alert status to meet at least once with the academic advisor. It is extremely important for this group of students to engage in the process of academic planning well in advance of graduation and as early in matriculation as possible.

With enrollment just starting to rebound and shrinking budgets continuing to be a real concern for law schools, resources can be a major impediment to hiring a professional academic advisor. However, the value far outweighs the expense. Like other challenges law schools are currently facing, now is the time to be creative and look for additional resources and support for this type of initiative. For example, due to student need and strict accreditation standards there are often extensive resources available for academic advising at the undergraduate level. Therefore, leveraging those resources (including funding) from your central campus might make what seemed impossible a reality at your law school.

In conclusion, Millennials need as much structured guidance and support as possible to fulfill their goal of academic success and passing the bar exam, and a professional academic advisor can be instrumental in that pro-

cess. Through this twoway relationship between student and advisor, Millennials will know how and where to access accurate

"Another
major ben-
efit of hav-
ing a law
school pro-
fessional
academic
advisor is
strategic
and target-
ed advis-
ing."

"Another major benefit of having a law school professional academic advisor is strategic ed advising. ” 


\begin{tabular}{|c|c|}
\hline $\begin{array}{l}\text { "Through } \\
\text { this two- } \\
\text { way rela- } \\
\text { tionship } \\
\text { between } \\
\text { student and } \\
\text { advisor, } \\
\text { Millennials } \\
\text { will know } \\
\text { how and } \\
\text { where to } \\
\text { access ac- } \\
\text { curate in- } \\
\text { formation } \\
\text { about re- } \\
\text { sources, } \\
\text { policies, } \\
\text { procedures } \\
\text { and re- } \\
\text { quirements } \\
\text { - while re- } \\
\text { ceiving in- } \\
\text { valuable } \\
\text { individual- } \\
\text { ized guid- } \\
\text { ance to } \\
\text { help them } \\
\text { along their } \\
\text { educational } \\
\text { journey. " }\end{array}$ & $\begin{array}{l}\text { Allen, Renee Nicole and } \\
\text { Jackson, Alicia, Contempo- } \\
\text { rary Teaching Strategies: } \\
\text { Effectively Engaging Mil- } \\
\text { lennials Across the Curric- } \\
\text { ulum (April } 5 \text { 6451). Univer- } \\
\text { sity of Detroit Mercy Law } \\
\text { Review, Forthcoming; Uni- } \\
\text { versity of Tennessee Legal } \\
\text { Studies Research Paper } \\
\text { No. } 325 \text {. Available at SSRN: } \\
\text { https://ssrn.com/ } \\
\text { abstract=2985145 }\end{array}$ \\
\hline
\end{tabular}

information about resources, policies, procedures and requirementswhile receiving invaluable individualized guidance to help them along their educational journey. Each of these components is essential to a successful and meaningful law school exstudent and advisor, Millennials

will know

how and

curate in-

about re

procedures

- while re-

ceiving in-

individual-

educational

journey. “

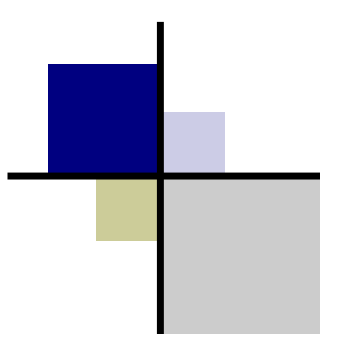

